\title{
Harry Currey: an appreciation
}

MB, MMED (Cape Town), FRCP (London)

ARC professor of rheumatology, The London Hospital Medical College 1974-87

Editor of the Annals of the Rheumatic Diseases 1983-88

Harry Currey first set foot in England as a naval rating in 1945. As a physician, he arrived in 1962 from Cape Town, where he had been senior registrar in medicine, having previously been in general practice for six years in Port Elizabeth. His arrival at Hammersmith Hospital was to enable him to attend the 'course', take the MRCP which, as anticipated, he passed at his first attempt, and to learn more rheumatology. One might say that like a mature student Harry became a mature house physician to Professor Eric Bywaters and Dr Tom Scott in 1962-3 and subsequently a mature senior house officer to Dr Will Tegner and Dr Michael Mason in the department of physical medicine and rheumatology at The London Hospital. In both these appointments he demonstrated his great acumen and experience in medicine to a degree that was unusual in the average house physician or senior house officer.

Harry and his family decided to stay in England, and his rapid rise to rheumatological fame began-senior registrar at The London Hospital 1964-5, sabbatical year with Dr Morris Ziff in Dallas 1966, the newly created ARC senior lecturer at The London Hospital 1965, from which position he was promoted to reader in 1970, and to a personal chair in 1974, which became the established ARC chair in 1983. In 1968 Will Tegner retired, being replaced by Dr Colin Barnes, and the team of Mason, Currey, and Barnes continued the expansion of rheumatology at The London Hospital led by the vision of Michael Mason.

Harry Currey with Michael Freeman and Barry VernonRoberts (now Professor of Pathology in Adelaide), each involved in research and teaching, respectively in rheumatology, orthopaedic surgery, and pathology, formed a combined research group, which became the Bone and Joint Research Unit at The London Hospital Medical College. In 1965-6 the Arthritis and Rheumatism Council financed the ARC building to house the unit and thus to provide it with adequate laboratories, offices, and seminar rooms.

As professor of rheumatology and director of the Bone and Joint Research Unit he developed a multidisciplinary research programme, the teaching programme for undergraduates, while maintaining his clinical activities in the department of rheumatology at The London Hospital. He instituted weekly department clinical conferences, $x$ ray review sessions, and research lectures.

During this time tragedy struck when Harry's first wife Crystal, herself a physician, died after prolonged illness in 1972. His strength of character allowed him to withstand this tragedy. In due course an engagement was announced between Harry and Jackie Harris, then senior registrar and now consultant in rheumatology, which led to one of Harry's nicknames. Michael.Mason had been less observant than usual and when Jackie told him of her engagement the question came back 'to Harry who?!'hence Dr Who.
Harry also played a central part in national rheumatological activities as president of the Heberden Societyo chairman of the ARC's research subcommittee, and editor of the ARC reports. He presented the Heberdem Round at The London Hospital in 1972 and the Phil Ellman lecture of the Royal College of Physicians in 197 . Having been largely responsible for an experimental and improved scientific programme at the European congres of rheumatology, Brighton 1971, Harry latterly became outspoken critic of large international conferences invol ing the reading of many short papers.

He has always been an enthusiastic author, contributing to many standard reference works, editing both Mason and Currey Clinical Rheumatology and Currey and Hul Rheumatology for GPs, and writing Essentials of Rheumar tology.

He became editor of the Annals in succession to Dr Tom Scott, a difficult example to follow. Under Harry Curreys editorship between 1983 and 1988 the Annals progressive grew in size and evolved into a monthly production. He maintained a tight check on the composition of the editorial board, on the standard of refereeing of papers and latterly succeeded in computerising all the editori records. In six years under his editorship 5500 pages and 1021 papers were published, representing an acceptance rate of approximately $50 \%$.

In his private life music, gardening, and walking are hig on his list of hobbies, and departmental parties held in the lovely garden which he and Jackie created were even never to be missed. Cruising inland waterways in a narros boat is a keen interest and in retirement more and more $\bar{f}$ his time is being devoted to a new addiction-golf. $\stackrel{\text { S }}{?}$

Many medical students, postgraduates in rheumatology and other branches of medicine, research workers, his immediate colleagues, all those who have read the Annot and other rheumatology text books, and, especially, mang patients owe much to Harry's teaching and practice $\mathscr{\mathscr { F }}$ academic rheumatology. We all wish him a happy and successful retirement knowing that he will continue to maintain close links with active rheumatology. 